ISSN 1422-8599

www.mdpi.org/molbank

Short Note

\title{
Synthesis of (2E)-2-(2,4,6-Trimethoxybenzylidene)indan-1-one
}

\author{
Abdullah Mohamed Asiri * and Mohammed Golam Rasul \\ Chemistry Department, Faculty of Science, King Abdul Aziz University, Jeddah 21413, P. O. Box \\ 80203, Saudi Arabia
}

*Author to whom correspondence should be addressed; E-mail: aasiri2@kau.edu.sa

Received: 5 December 2008 / Accepted: 12 January 2009 / Published: 15 January 2009

Keywords: 1-Indanone, nonlinear optics; conjugated chromophores.

Donor-acceptor (D-p-A) dyestuff and colorants represent a vast majority of organic chromogens. Such compounds have found many applications such as in dyeing of fabric, coloring of toners, and in image forming and optical information storage technologies. Some of these compounds are also used as sources of tunable (dye laser) radiation [1-3].

Recently, we synthesised a series of benzylidenes based on cyclopentanone and its cyclpentylidene malononitrile condensate [4]. In this paper, we report the synthesis of (2E)-2-(2,4,6-trimethoxybenzylidene)indan-1-one (3) [5] as a candidate donor-acceptor conjugated dye for possible applications in third order nonlinear optics.<smiles>COc1cc(OC)c(C=O)c(OC)c1</smiles>

1<smiles>O=C1CCc2ccccc21</smiles>

2

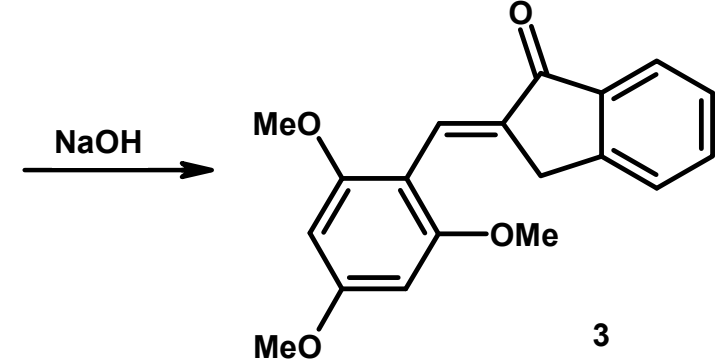

3

2,4,6-Trimethoxybenzaldehyde (2.0 g, $0.01 \mathrm{~mol})$ and 1-indanone (1.34 g, $0.01 \mathrm{~mol})$ were dissolved in $25 \mathrm{ml}$ of ethanol and then heated to boiling before sodium hydroxide $(10 \mathrm{ml}, 0.10 \mathrm{M})$ was added. The reaction mixture was refluxed for $3 \mathrm{~h}$, cooled and then the precipitate was filtered and recrystallized from ethanol.

m.p. $185^{\circ} \mathrm{C}$ 
Yield: $68 \%$

Color: Yellow crystals

IR; $v\left(\mathrm{~cm}^{-1}\right): 2934(\mathrm{C}-\mathrm{H}), 1685(\mathrm{C}=\mathrm{O}), 1134(\mathrm{C}-\mathrm{O})$.

${ }^{1} \mathrm{H}$ NMR;(DMSO-d $d_{6}, 400 \mathrm{MHz}$ ): 7.90 (d, $\left.1 \mathrm{H}, J=8.0 \mathrm{~Hz}, \mathrm{H}_{\text {aromatic }}\right), 7.83$ (s, 1H, olefinic H), 7.57 (t, $\left.1 \mathrm{H}, J=7.6 \mathrm{~Hz}, \mathrm{H}_{\text {aromatic }}\right), 7.46$ (d, $\left.1 \mathrm{H}, J=7.6 \mathrm{~Hz}, \mathrm{H}_{\text {aromatic }}\right), 7.37$ (t, H, $J=7.6 \mathrm{~Hz}, \mathrm{H}_{\text {aromatic }}$ ), 6.20 (s, $2 \mathrm{H}, \mathrm{H}_{\text {aromatic }}$ ), 3.89 (s, 9H, OMe), 1.71 (s, 2H, $\mathrm{CH}_{2}$ ).

Elemental analysis: Calculated for $\mathrm{C}_{19} \mathrm{H}_{18} \mathrm{O}_{4}$ : C, 73.53\%, H, 5.85\%; Found: C, 73.68\%, H, 5.91\%

\section{Acknowledgements}

The authors would like to thank King Abdul Aziz City of Science and technology for the financial support through the grant No. At-24-72.

\section{References and Notes}

1. Fabian, J.; Hartmann, H. Light Absorption of Organic Colorants; Springer Verlag: Berlin, 1980.

2. Asiri, A. M. Synthesis and characterization of dyes exemplified by 2-arylidene-1dicyanomethyleneindane. Dyes and Pigments 1999, 42, 209.

3. Attia, A.; Michael, M. Azachalcones. Part 2: Reactions of 3,3-diazachalcones. Pharmazie 1982, 37,551 .

4. Asiri, A. M.; Synthesis and Absorption Spectral Properties of Bis-methine Dyes Exemplified by 2,5-Bis-arylidene-1-dicyanomethylene-cyclopentanes. Bull. Korean Chem. Soc. 2003, 24, p 426.

5. The title compound was obtained as a single isomer, accotrding to TLC; assignment of the $E$ configuration is based on the chemical shift ( $7.83 \mathrm{ppm})$ of the olefinic proton.

(C) 2009 by the authors; licensee Molecular Diversity Preservation International, Basel, Switzerland. This article is an open-access article distributed under the terms and conditions of the Creative Commons Attribution license (http://creativecommons.org/licenses/by/3.0/). 